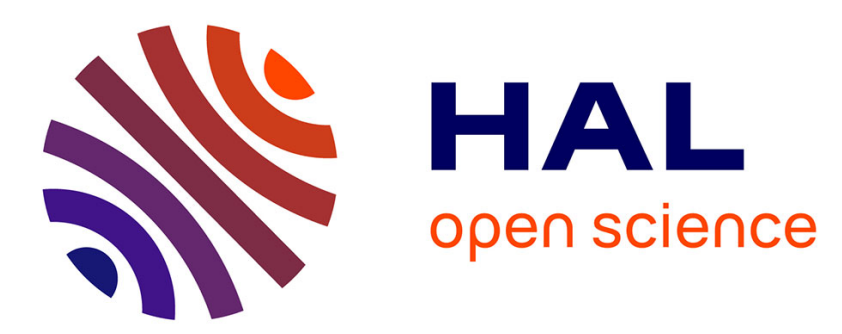

\title{
Estimation of bone material properties using an inverse finite element method
}

\author{
Anais Garo, Pierre-Jean Arnoux, Carl-Erik Aubin
}

\section{To cite this version:}

Anais Garo, Pierre-Jean Arnoux, Carl-Erik Aubin. Estimation of bone material properties using an inverse finite element method. Computer Methods in Biomechanics and Biomedical Engineering, 2009, Vol12,Issue S1, p121-122. 10.1080/10255840903080851 . hal-00849520

\section{HAL Id: hal-00849520 \\ https://hal.science/hal-00849520}

Submitted on 31 Jul 2013

HAL is a multi-disciplinary open access archive for the deposit and dissemination of scientific research documents, whether they are published or not. The documents may come from teaching and research institutions in France or abroad, or from public or private research centers.
L'archive ouverte pluridisciplinaire HAL, est destinée au dépôt et à la diffusion de documents scientifiques de niveau recherche, publiés ou non, émanant des établissements d'enseignement et de recherche français ou étrangers, des laboratoires publics ou privés. 


\title{
Estimation of bone material properties using an inverse finite element method
}

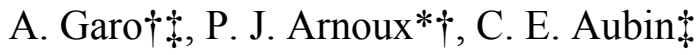 \\ †Laboratoire de Biomécanique Appliquée-UMRT 24, INRETS/Université de la Méditerranée, \\ Marseille, France \\ †Département de Génie Mécanique, École Polytechnique, Montréal, Canada \\ *Corresponding author. Email: pierre-jean.arnoux@inrets.fr
}

Keywords: Bone, dynamic properties, finite element model, vertebra

\section{Introduction}

Burst fractures are common fractures resulting from impact loading and can have severe consequences such as neurological deficits [1]. The biomechanical process which leads to burst fracture is still debated. Finite element models (FEM) could further our knowledge on burst fracture mechanism. A precise evaluation of the mechanical properties of bone tissues is a critical issue when creating these models [2].

The aim of this study was to evaluate the mechanical properties of bone components of the vertebral body. An inverse finite element strategy was used to estimate the properties of cortical and trabecular bone. These mechanical properties have been evaluated at two velocities in order to investigate the influence of the displacement rate.

\section{Methods}

A finite element model of a human L5 vertebral body was created. Cortical and endplate bones were represented by 3 -node shell elements with a uniform thickness of $0.4 \mathrm{~mm}$. The trabecular core of the vertebra was meshed using tetrahedral elements. The material properties of bone were defined as homogeneous isotropic and modeled with a Johnson-Cook elasto-plastic material law [3].

The vertebral body was simulated in compression to mimic the experimental tests made by Ochia et al.[4]. Layers of cement were modeled on the top and the bottom of the vertebra to reproduce the experimental conditions and to ensure a vertical compression of the vertebra (Fig. 1). The superior layer was allowed to translate vertically at a constant velocity. The model was tested at low $(10 \mathrm{~mm} / \mathrm{s})$ and high displacement rates $(2500 \mathrm{~mm} / \mathrm{s})$.

The analysis was performed using the Radioss explicit finite element software (Version 4.4, Altair HyperWorks Inc.). The failure load and energy absorbed at failure (area under the loaddisplacement curve) were used to compare the prediction of the model and the experimental results.

The mechanical properties of bone components were obtained using an optimization method. The parameters investigated were the ultimate stress $\left(\sigma_{\max }\right)$ and the ultimate strain $\left(\varepsilon_{\max }\right)$ for both cortical and trabecular bones. The yield stress and yield strain were assigned as ratios of the ultimate stress and ultimate strain respectively. The optimization method was a Central Composite Design (CCD) [5] carried out using the Statistica Software (StatSoft, Inc. 2001). It was composed of a full factorial design $(+1,-1)$, a center point $(0)$ and star points $(+2,-2)$. The objective was to minimize the difference between the experimental and simulated values of load and energy at failure. The same protocol was used at high $(2500 \mathrm{~mm} / \mathrm{s})$ and low $(10 \mathrm{~mm} / \mathrm{s})$ displacement rates.

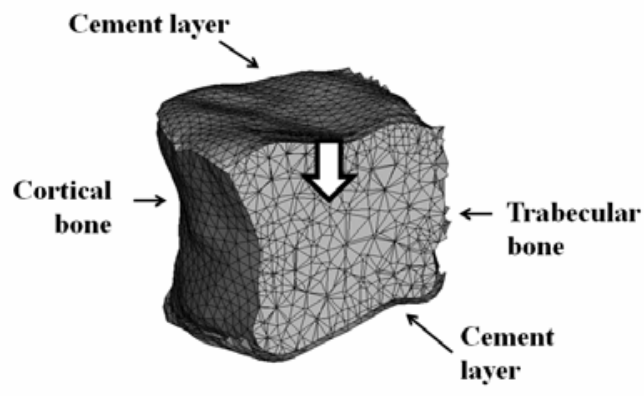

Figure 1 : Finite element model of the vertebral body impacted on the superior endplate 


\section{Results and Discussion}

Table 1 presents the results of the optimization method. The ultimate stress of trabecular and cortical bones were in the corridor of published values [6-8]. The ultimate strain of the cortical bone was higher $(7.1-8 \%)$ than values from the literature which are usually between $2 \%$ in quasistatic and $6 \%$ in dynamic loading [6]. The difference could be explained by differences between cortical bone organization in vertebra vs. long bone mid-shaft samples generally used in such mechanical testing.

The ultimate stress and strain of trabecular bone were higher at high displacement rate, while the ultimate stress of cortical bone was lower and the ultimate strain was higher at low displacement rate (Table1). The displacement rate thus influences the material properties of vertebral bones, as it was also found in related published experimental studies [6,9].

A future direction could be to improve the elastoplastic law used for bone materials by taking into account the strain rate dependency.

Table 1 : Material properties of bone computed at two displacement rates

\begin{tabular}{lcc}
\hline \hline Parameters & $\mathrm{V}=2500 \mathrm{~mm} / \mathrm{s}$ & $\mathrm{V}=10 \mathrm{~mm} / \mathrm{s}$ \\
\hline Trabecular Bone & & \\
$\mathrm{E}(\mathrm{MPa})$ & 93.7 & 48.7 \\
$\varepsilon_{\mathrm{y}}(\%)$ & 5 & 4 \\
$\varepsilon_{\max }(\%)$ & 10 & 8 \\
$\sigma_{\mathrm{y}}(\mathrm{MPa})$ & 4.7 & 1.95 \\
$\sigma_{\max }(\mathrm{MPa})$ & 6.25 & 2.6 \\
Cortical Bone & & \\
E $(\mathrm{MPa})$ & 4014 & 2625 \\
$\varepsilon_{\mathrm{y}}(\%)$ & 3.55 & 4 \\
$\varepsilon_{\max }(\%)$ & 7.1 & 8 \\
$\sigma_{\mathrm{y}}(\mathrm{MPa})$ & 142.5 & 105 \\
$\sigma_{\max }(\mathrm{MPa})$ & 190 & 140 \\
\hline Load at failure (N) & & \\
Experimental results & $9699 \pm 2110$ & $4908 \pm 2729$ \\
Numerical results & 10104 & 4996 \\
Energy at failure (N.m) & & \\
Experimental results & $6.43 \pm 1.89$ & $4.26 \pm 3.88$ \\
Numerical results & 5.91 & 3.2 \\
\hline \hline
\end{tabular}

\section{Conclusions}

This study presented a statistical method to evaluate the mechanical properties of bone components of the vertebral body at two loading rates (quasi-static and dynamic loadings). The primary results showed the effects of the displacement rate and it highlighted the importance to adapt the properties according to the loading conditions in dynamic simulations. Further studies are under way to evaluate precisely the mechanical properties of the bony endplates. Once obtained, these properties will be integrated into a more detailed model of a motion segment. This model would allow testing the influence of bone parameters in physiologic conditions and reproducing more accurately burst fractures.

\section{References}

[1] Dai L.-Y. et al., A review of the management of thoracolumbar burst fractures, Surgical Neurology, 2007, 67, 221-231.

[2] Wilcox R. K. et al., A dynamic investigation of the burst fracture process using a combined experimental and finite element approach, Eur Spine J, 2004, 13, 481-8.

[3] Willkenmuller G. and Kayvantash K., Radioss theoretical manual, 1999.

[4] Ochia R. S. et al., Effect of loading rate on endplate and vertebral body strength in human lumbar vertebrae, J. Biomechanics, 2003, 36, 1875-81

[5] http://www.cours.polymtl.ca/mth6301/

[6] Hansen U. et al., The effect of strain rate on the mechanical properties of human cortical bone, J Biomech Eng, 2008, 130, 011011.

[7] Kopperdahl D. L. and Keaveny, T. M., Yield strain behavior of trabecular bone, $J$. Biomechanics, 1998, 31, 601-608.

[8] Shim V. P. W. et al., Characterisation of the dynamic compressive mechanical properties of cancellous bone from the human cervical spine, Int. J. of Imp. Eng., 2005, 32, 525-540.

[9] Linde F. et al., Mechanical properties of trabecular bone. Dependency on strain rate, $J$. Biomechanics, 1991, 24, 803-809.

\section{Acknowledgments}

This research was funded by NSERC (Canada) and INRETS (France). 